\title{
羊毛繊維の酸化染料染色における細胞膜複合体の役割
}

\author{
京都女子大学家政学部 上甲恭平・吉勝友美・坂田佳子
}

\section{Function of the Cell Membrane Complex on Dyeing of Wool Fibers with Oxidation Dye}

\author{
Kyohei Joko, Yumi Yoshikatsu, and Keiko Sakata
}

Kyoto Women's University, Kita-hiyoshi, Imakumano, Higashiyama-ku, Kyoto 605-8501, Japan

\begin{abstract}
The effect of a modification of cell membrane complex (CMC) on the color developed by oxidation dye reaction of three precursors with a coupler was investigated. From the results of dyeing in the presence of ascorbic acid and ethylenediaminetetraacetic acid (EDTA), it was found that the dye uptake of the wool samples modified with 98$99 \%$ formic acid decreased apparently compared to that of unmodified wool sample. The decreased extent of their uptake was dependent on the extent of modification of CMC. However, if unmodified and CMC-modified wool samples were dyed with the preformed dyeing system, the dye uptake of all the modified samples ware approximately same as that of unmodified sample. Also, it was found that the mechanically pulverized cortex cells seem to be inactive to dyeing with both oxidative dyeing system and preformed dyeing system. Consequently, it is assumed that not only the CMC regions play an important role as accumulation regions of the finished dye, but also any components of the intercellular material take strongly part in color formation on the wool fibers as catalyst.
\end{abstract}

(Received 2 May, 2006 ; Accepted 23 August, 2006)

\section{1. 緒 言}

現在, ヘアカラーリングは消費者の新しい生活習慣と してすでに定着している.ヘアカラーリング剤は使用す る染料の種類や染色効果の持続力に応じて一時染毛料, 半永久染毛料, 永久染毛剂に分類されている. その中で 最も利用されているのが, 永久染毛剂に分類されている 酸化染料である $[1]$.

酸化染料は, 酸化染料中間体と呼ばれる無色の芳香族 アミン化合物が，酸化剤の作用により酸化重合すること によって繊維に染着する有色化合物のことをいう。酸化 染料中間体には, プレカーサー, カップラーの 2 種の芳 香族化合物群があり, 染色の際はプレカーサーとカップ ラーを混合して使用する。染料の発色は，まずプレカー サーが酸化剂の過酸化水素により酸化され, 反応活性イ ミン体となることから始まる。この反応活性イミン体が カップラーと反応することによりロイコ染料が形成され, ロイコ染料がさらに酸化して酸化染料が生成され, 発色 する $[2]$.

溶液中での反応については, 以上のように考えられて いる.しかし, ケラチン繊維の染色における反応機構に ついては溶液中と同様の反応が繊維内で起こっていると の考えが主流であるが, 詳しい反応機構や染着領域につ いてはほとんど検討されていない $[3,4]$. 特に, ケラチン 繊維の組織構造との関係を取り扱った研究は見あたらな
い.

そこで，本報告ではケラチン繊維に対する酸化染料の 染着機構や染着領域に関寸る知見を得ることを目的とし て，ケラチン䋊維以外の繊維に対する染色性および羊毛 繊維に対する酸化染料を用いた染色における羊毛緎維の 構成組織の構造変化の影響について検討した. 特に, こ こでは細胞膜複合体 $(\mathrm{CMC})$ の役割に着目した.

\section{2. 実 験}

\section{1 試料}

羊毛試料には， $1 \%$ ドデシル硫酸ナトリウム溶液で処理 したメリノ羊毛布 (水系洗濯用標準梳毛織物 : クロッツ・ ベッケルト・ジャパン社製)を用いた。 その他の繊維試料 には, ポリエステル, 絹, アクリル, レーヨン, 羊毛, ナイロン, 綿繊維で構成された多繊維交織布を水洗いし て使用した。

コルテックス細胞は, 高速回転衝撃型粉砕器 P-14 ロー タピスピードミルにより機械的に粉砕することによって 作製した. ただし, 実験にはクチクル細胞等の分離は行 わずに混合状態で用いた.

\section{2 試薬}

酸化染料中間体はパラアミノフェノール $(\mathrm{pAP})$, パラ フェニレンジアミン (pPDA), ジアミノトルエン二塩酸塩 $(\mathrm{pAT})$, パラアミノオルトクレゾール $(\mathrm{pAOC})$ を使用した. 
その他, $25 \%$ アンモニア水, エチレンジアミン四酢酸 二ナトリウム二水塩 (EDTA), L (+) アスコルビン酸, 過酸 化水素, 炭酸アンモニウム (炭酸水素アンモニウムとカル バミン酸アンモニウムの混合物)， 98-99\% ギ酸は市販試 薬 1 級あるいは特級を使用した。

\section{3 ギ酸処理}

羊毛布を 98-99\% ギ酸溶液に浴比 $1: 500$ となるように 浸漬し，常温で 1 4 日間，ゆっくりかくはんさせながら 処理した. 処理後, イオン交換水で数回洗浄し, さらに 蒸留水に 1 日浸漬させた後, 脱水, 風燥した.

\section{4 染色方法}

染色は，以下に示す 3 種の方法により行った.

A 法 : pAP/pAOC 系, pPDA/pAOC 系および pAT/pAOC系 のいずれの系おいてもそれぞれの濃度が $0.01 \mathrm{~mol} / \mathrm{L}$ となる ように蒸留水 $100 \mathrm{~mL}$ に溶解した。 溶液の $\mathrm{pH}$ は各系とも に $25 \%$ アンモニア水により $\mathrm{pH} 10$ に調整した後，3 日間室 温放置し溶存酸素により酸化重合させた酸化染料の溶液 を染料溶液として使用した。染色は $100 \mathrm{~mL}$ のフラスコに $20 \mathrm{~mL}$ の染料溶液を入れ, ウォーターバスで $30^{\circ} \mathrm{C}$ に調温 した. その後, 沸騰水で膨潤させた羊毛試料 $0.5 \mathrm{~g}$ をフラ スコに投入し，静置状態で 30 分間浸漬処理を行った。染 色後は試料を蒸留水で 1 分閒洗浄し, 再び 1 分間蒸留水 で洗浄した後, 常温で自然乾燥させた.

B 法 : pAP/pAOC 系, $\mathrm{pPDA} / \mathrm{pAOC}$ 系および $\mathrm{pAT} / \mathrm{pAOC}$ 系 のいずれの系おいても，I液として，プレカーサーおよ びカップラーを $0.001 \mathrm{~mol}, 25 \%$ アンモニア水を $4 \mathrm{~mL}$ 加え, 蒸留水で全体積を $100 \mathrm{~mL}$ とすることで調整した。 II 液に は， $3.6 \%$ 過酸化水素溶液を用いた。 染色直前に I 液と II 液を等量混合し染色溶液とした。 各混合染色溶液の $\mathrm{pH}$ は 特に調節しなかったが $\mathrm{pH} 10.1 〜 \mathrm{pH} 10.4$ の範囲にあった. 染色は混合染色溶液を用いること以外はA 法に準じて 行った.

C 法 : pAP/pAOC 系, pPDA/pAOC 系および pAT/pAOC 系 のいずれにも，I液として，プレカーサーおよびカップ ラーを $0.001 \mathrm{~mol}$, EDTA0.001 mol, L $(+)$ アスコルビン酸
$0.002 \mathrm{~mol}$ を加え, 全体積をあらかじめアンモニア水で $\mathrm{pH}$ 9.95 に調整した炭酸アンモニア水溶液(炭酸アンモニア換 算濃度: $0.1 \mathrm{~mol} / \mathrm{L})$ で $100 \mathrm{~mL}$ とした。 II 液には高濃度の $5.25 \%$ 過酸化水素溶液を使用した。B 法と同様に染色直前 に I 液と II 液を等量混合し，その $\mathrm{pH}$ を 9.95 となるよう にアンモニア水により調整したものを染色溶液とした. 染色はB 法に準じた。

なお，B 法に用いた染色溶液は，溶液中で酸化重合が 進行するため酸化染料を含む着色溶液である。これに対 し，C法では，EDTA とアスコルビン酸の作用により酸化 重合反応が抑制され，発色した酸化染料を含まない無色 の溶液である.さらに, この溶液は数時間経過後も無色 のままであり安定した状態にあるが, 混合後十数分放置 した溶液では空気と触れている液表面が着色しており， 気/液界面では酸化重合反応が進行している。（図 6 参照)

\section{5 表面染料濃度の測定方法}

染色試料の染着量は, 同時測光方式分光式色差計 SQ2000 (日本電色工業株式会社) を用いて試料表面の反射率 を測定し，Kubelka-Munk 関数により表面染色濃度を表す $\mathrm{K} / \mathrm{S}$ 值を求め, その最大吸収波長での值で表した.

\section{3. 結果と考察}

\section{1 A，B，C 法による羊毛布の染色}

まず，溶液状態の異なる染色溶液を用いた場合の羊毛 繊維への染色について調べた。図 1 はA 法, B 法, C 法 の染色方法で染色した羊毛布の表面反射率より求めた K/S 一波長 $(\lambda)$ 曲線である。

この図から明らかなように，すべての組み合わせにつ いて, いずれの染色方法でも羊毛繊維の染色は可能であ ることがわかる.さらに, いずれの系の染色でも A 法, $\mathrm{B}$ 法, $\mathrm{C}$ 法で得られた染色試料の $\mathrm{K} / \mathrm{S}-\lambda$ 曲線の形は一致 しており，最大ピーク值が同一波長であることが確認で きる。それぞれの系で得られたスペクトルの最大吸収波 長は, pAP/pAOC系で $480 \mathrm{~nm}, \mathrm{pPDA} / \mathrm{pAOC}$ 系で $520 \mathrm{~nm}$,
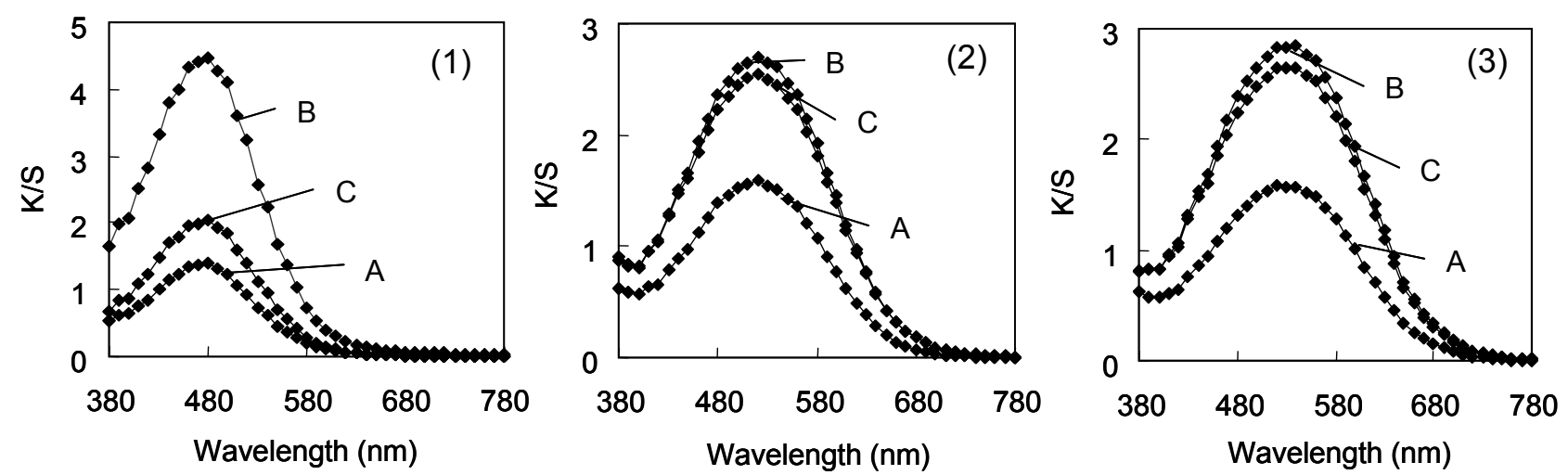

Fig. 1 Plots of K/S versus wavelength for the wool fabrics dyed at $30^{\circ} \mathrm{C}$ for $30 \mathrm{~min}$ using the dyeing conditions $\mathrm{A}, \mathrm{B}$, and $\mathrm{C}$. A : dyeing condition $\mathrm{A}, \mathrm{B}$ : dyeing condition $\mathrm{B}, \mathrm{C}$ : dyeing condition $\mathrm{C}$.

(1) pAP/pAOC system, (2) pPDA/pAOC system, (3) pAT/pAOC system 
pAT/ pAOC 系で 520nm である. つまり，いずれの染色法 においても酸化によって反応染着した染料は同一構造の ものであると考えられる.さらに，これまでの研究 $[5,6]$ によれば，いずれの系においても二環体である染料が合 成され, pAP/pAOC系では2-アミノ-5-メチルインドフェ ノール, pPDA/pAOC系では2-アミノ-5-メチルインドア
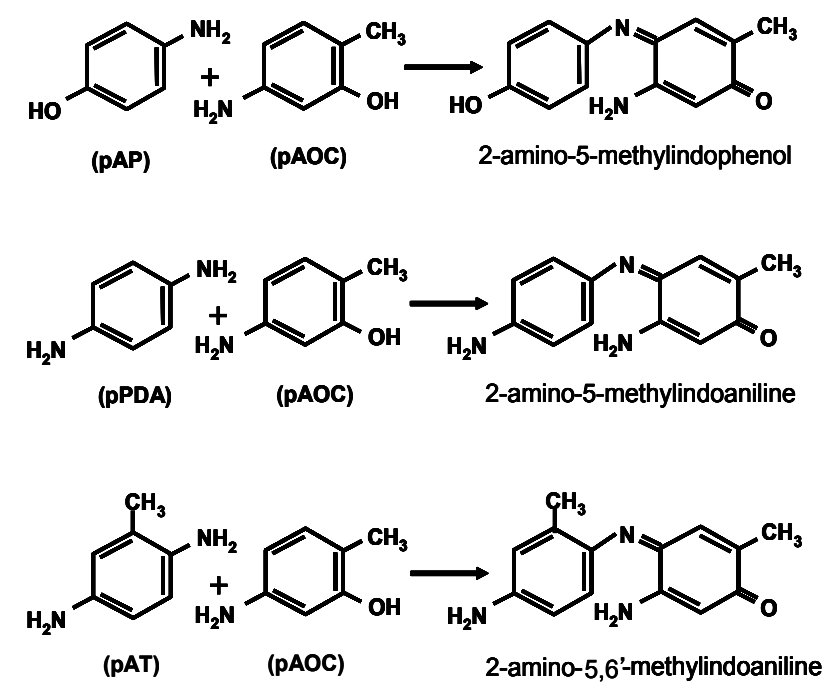

Fig. 2 Indo dyes formed in oxidative dyeing.
ニリン, pAT/pAOC系では同様に2-アミノ-5, 6’メチル インドアニリンであると考えられる(図 2).

\section{2 各種繊維に対する染色性}

続いて, 羊毛繊維以外の繊維に対する酸化染料の染色 性について検討した。

図 3 に各繊維に対する $\mathrm{pAP} / \mathrm{pAOC}$ 系, $\mathrm{pPDA} / \mathrm{pAOC}$ 系, $\mathrm{pAT} / \mathrm{pAOC}$ 系の A 法により $30^{\circ} \mathrm{C} ， 30$ 分間染色した時の最 大 $\mathrm{K} / \mathrm{S}$ 值を示した.

まず，pAP/pAOC系での染色であるが，主に羊毛，絹， ナイロンのポリアミド系繊維に染まり, レーヨン, 綿の セルロース系繊維にはわずかに染まるが，アクリル，ポ リエステルの合成䋊維にはほとんど染まらないことがわ かる.

また, pPDA/pAOC系および pAT/pAOC 系のいずれの 染色においても, レーヨンが高い K/S 值を示すことを除 いて pAP/pAOC 系とほぼ同様の結果が得られた。

つぎに, B 法による $\mathrm{pAP} / \mathrm{pAOC}$ 系, PPDA $/ \mathrm{pAOC}$ 系, $\mathrm{pAT} / \mathrm{pAOC}$ 系の $30^{\circ} \mathrm{C}, 30$ 分染色の各種綫維の最大 $\mathrm{K} / \mathrm{S}$ 值 を図 4 に示す。この図から, いずれの系による染色結果 においても, 羊毛・絹・ナイロンのポリアミド系繊維は 染着しており，A 法とほぼ同様の傾向が見られた.

このように, 溶液中で酸化重合が進行し酸化染料が存
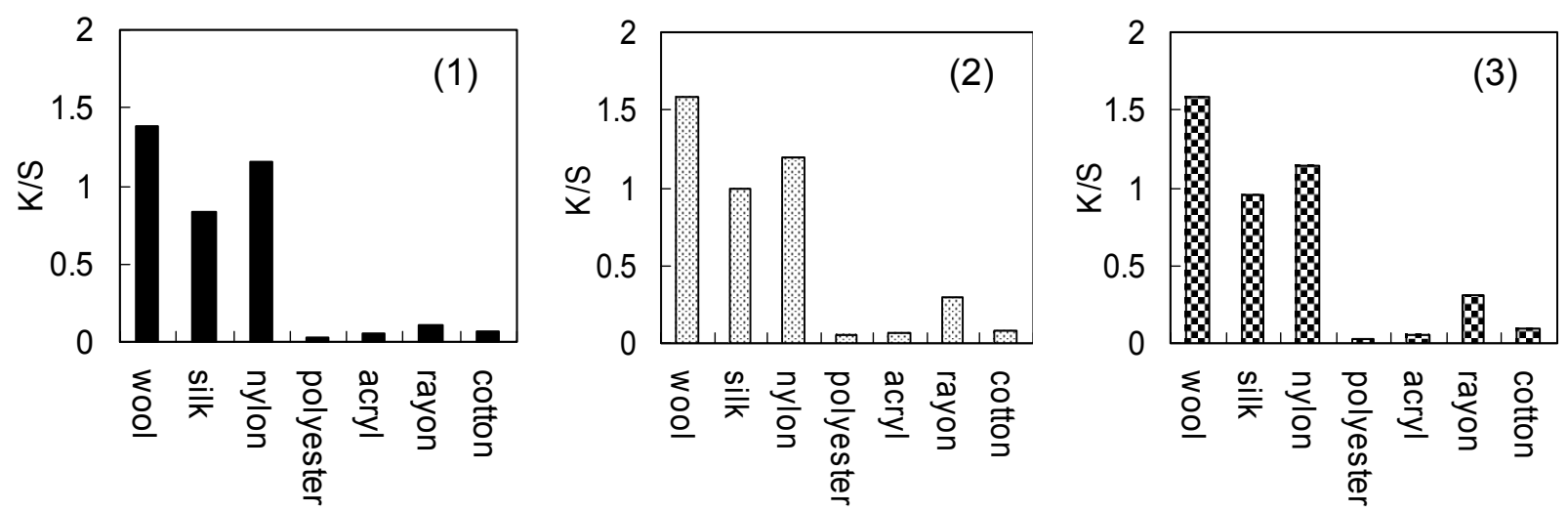

Fig. 3 Dye uptake of seven different fabrics dyed at $30^{\circ} \mathrm{C}$ for $30 \mathrm{~min}$ using the dyeing condition $\mathrm{A}$.

(1) $\mathrm{pAP} / \mathrm{pAOC}$ system, (2) pPDA/pAOC system, (3) pAT/pAOC system
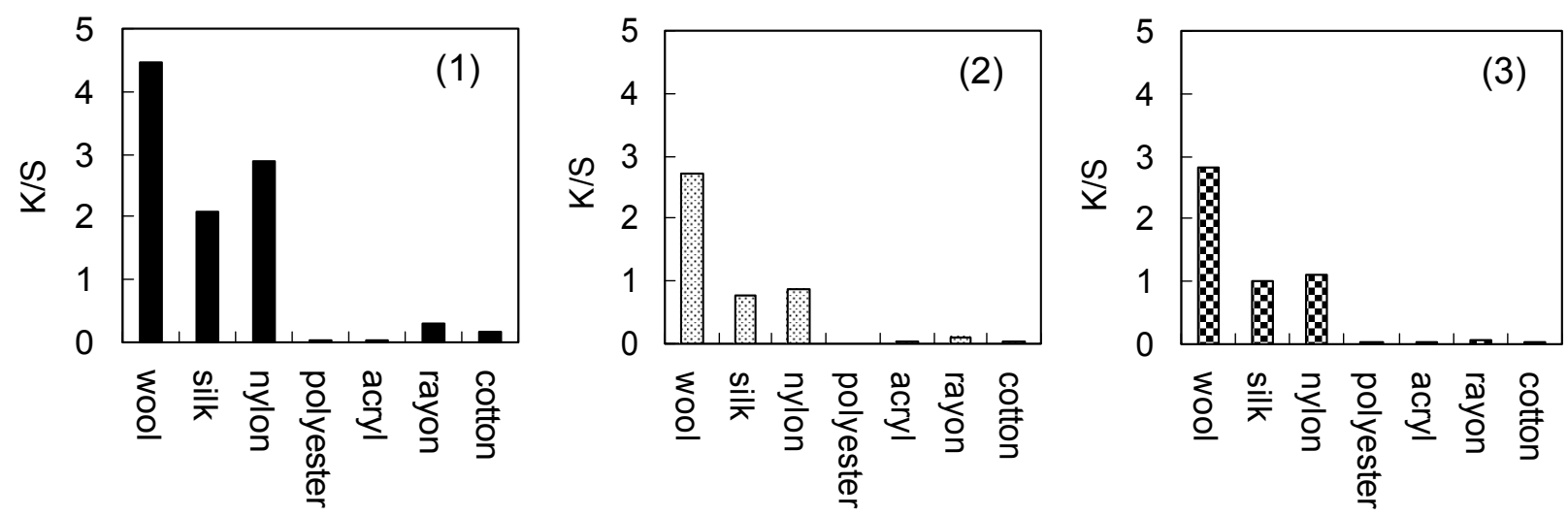

Fig. 4 Dye uptake of seven different fabrics dyed at $30^{\circ} \mathrm{C}$ for $30 \mathrm{~min}$ using the dyeing condition $\mathrm{B}$. (1) $\mathrm{pAP} / \mathrm{pAOC}$ system, (2) pPDA/pAOC system, (3) pAT/pAOC system 

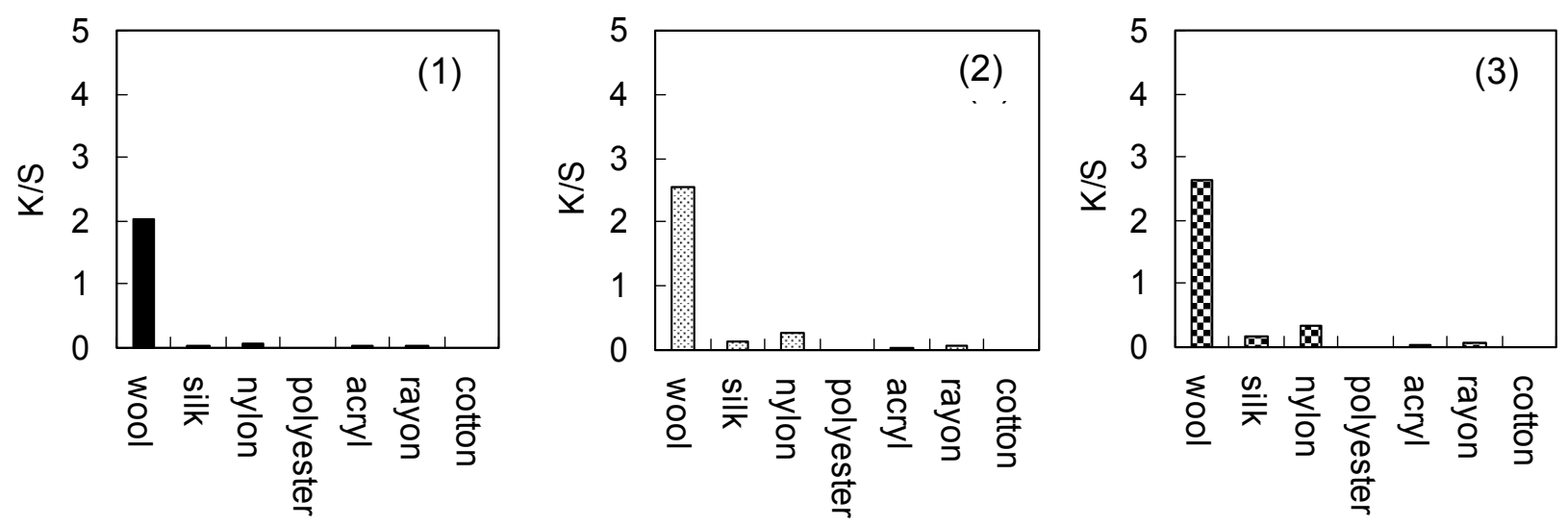

Fig. 5 Dye uptake of seven different fabrics dyed at $30^{\circ} \mathrm{C}$ for $30 \mathrm{~min}$ using the dyeing condition $\mathrm{C}$.

(1) $\mathrm{pAP} / \mathrm{pAOC}$ system, (2) pPDA/pAOC system, (3) pAT/pAOC system

在する染色では，ポリアミド系繊維はよく染着されてお り, 酸化重合により生成した酸化染料は羊毛繊維以外に 絹およびナイロンに対しても親和性があると云える。し かし, 綿やレーヨンに対しては酸化染料の分子量が低い ため親和力が小さく, 収着されるが染着しないと考えら れる.さらに，ポリエステルやアクリルでは，これらの 繊維の $\mathrm{Tg}$ が高く，酸化染料の分子量が小さいといえども， ガラス状態では繊維内部に浸透することができないと考 えられた。

ところが，C法による $\mathrm{pAP} / \mathrm{pAOC}$ 系, $\mathrm{pPDA} / \mathrm{pAOC}$ 系, $\mathrm{pAT} / \mathrm{pAOC}$ 系の $30^{\circ} \mathrm{C}, 30$ 分染色では, 図 5 に示したよう に, pPDA/pAOC系および pAT/pAOC系でナイロンおよ び絹がわずかに染着していることが認められるものの, 羊毛繊維以外の繊維は全く染着しないことがわかる.

\section{3 C 法での羊毛繊維の着色挙動}

A 法，B 法では溶液が着色しているため染着の様子を 観察することは困難であるが，C法での染色溶液は無色 であるため, 発色の様子を観察することは可能である.

図 6 は羊毛布をアスコルビン酸/EDTA 含有 $\mathrm{pAP} / \mathrm{pAOC}$ 系溶液に浸漬し, 室温で放置した際の着色挙動を写真撮 影したものである。左の試料ビンは溶液のみ，右のそれ は羊毛布を入れたものである.

この図を詳しく観察したところ, 染色開始 5 分後では 溶液はどちらも変化していないが，羊毛布はほんのりと 紫色に変化し始めている. 10 分後, 羊毛布は布全体が紫 色に着色されるが，よく観察すると布目がより濃く着色 していることがわかる. その後時閒経過ともに, 布を構 成している糸が濃く着色されている様子が観察できるが, 布端の然りがほぐれた糸では色目は薄く, 濃く見えてい る部分は繊維間の溶液中にある染料によるものであるこ とがわかる。

一方，溶液の変化であるが，ブランク溶液は既に述心゙ たように, 空気と接触する表面で着色が認められるのみ であるが，布を含む溶液では，羊毛布に接触している溶 液が着色しており, 羊毛布表面付近以外の溶液部分では 30
分経過後も溶液に変化がなく, 溶液中では染料は合成さ れていないことがわかる，さらに詳しく観察すると，布 表面付近に重合した染料が溶液中に拡散することを示す かのように, 染料が䋊維から沸き立つように溶液中に流 れ出ている様子が観察できる.

一方, 絹, ナイロン, アクリルを浸漬した染色溶液で は，試料布が着色する様子は全く観察されなかった。し かし，図 5 に示したように，ナイロンや絹は若干の染着 が得られている. 染色試料は染浴より取り出した時点で は溶液中で観察したように無着色であったが，水洗いし， 自然乾燥している間に発色することを確認した。この現 象は, 染色溶液に含まれる成分の一部が䋊維内に浸透し, 還元剂等の作用により酸化重合反応が抑制されているた めに発色しなかったが, 水洗により還元剤の一部が脱着 したことによって酸化反応が進み発色したものと考えら れる。

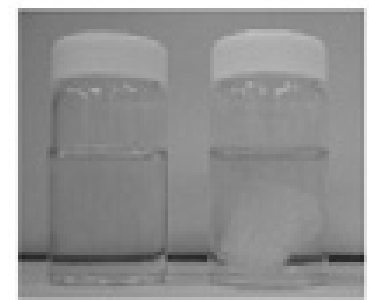

After 5 minutes

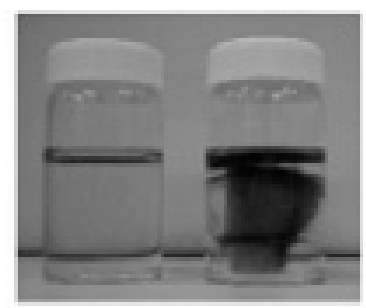

After 20 minutes

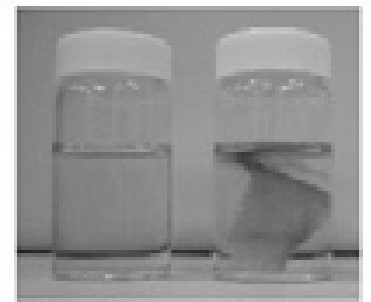

After 10 minutes

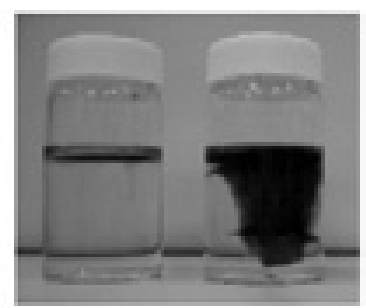

After 30 minutes
Fig. 6 The time-dependent change of samples of dye solution and wool fabric dyed at $30^{\circ} \mathrm{C}$ using the dying condition $\mathrm{C}$. 
以上の結果を総合すると, $\mathrm{pAP} / \mathrm{pAOC}$ 系, $\mathrm{pPDA} / \mathrm{pAOC}$ 系および pAT/pAOC系のいずれも，A法では，主に染浴 中で酸化重合した酸化染料が浸透吸着したことによる染 色であるが，C法では，羊毛繊維と接触することにより 酸化重合反応が進み繊維が染着される. 寸なわち, 酸化 染色機構の過程に液/固界面反応が含まれていると考えら れる。したがって, B 法での染色には, 重合酸化染料の 染着だけでなく C 法での染色と同様の酸化反応による染 着も含まれていることになる.

\section{4 ギ酸処理羊毛布の染色性}

C 法による染色では, 羊毛繊維のみが染色され, その 染色は繊維と接触することにより酸化重合反応が進むこ とから, 酸化染料中間体の酸化重合反応に羊毛繊維の固 有の組織構成成分が深く関与していることが示唆される.

羊毛の染色では, 染料のイオン性, 疎水性等の特性に より見かけの吸着挙動は異なるが, 染料の繊維内部への 初期浸透拡散には, クチクル細胞間の CMC が深く関与し ていることは広く知られている $[5,6]$. したがって, 酸化 染色系においても酸化染料中間体や酸化反応物も同様の 機構で羊毛䋊維内に浸透するものと考えられる.

また, $\mathrm{CMC}$ は有機酸であるギ酸や有機溶媒であるアル コールで処理することによって CMC の構成成分である非
ケラチンタンパク質や脂質が抽出され, CMC の構造が崩 れることはすでによく知られた事実である[7-9].

そこで，本実験においてはギ酸を用いて CMC を構造変 化させ, 改質された繊維への染着性を調べることから酸 化染料を用いた染色に対する CMC の影響について検討し た.

図 7 は未処理羊毛布と所定時間ギ酸処理したギ酸羊毛 布を C 法により $\mathrm{pAP} / \mathrm{pAOC}$ 系, pPDA/pAOC 系および pAT $/ \mathrm{pAOC}$ 系で $30^{\circ} \mathrm{C}, 30$ 分間染色した時の $\mathrm{K} / \mathrm{S}$ 值を示した図 である. pAP/pAOC 系, pPDA/pAOC 系および pAT/ pAOC 系のいずれにおいても, 未処理羊毛布に比べてす心゙ての ギ酸処理羊毛布の K/S 值は低下寸ることがわかる.

また，1日〜4 日のギ酸処理羊毛布については K/S 值が ほとんど変わらない結果が得られた。これらの結果から, 羊毛緎維の酸化染料染色には繊維構成組織である CMC 領 域が深く関与していることがわかる.

ところで, 染着量が低下する要因を挙げると, 既に述 ベたギ酸処理の作用から，(1) CMC 構成成分の抽出にと もなう構造変化により酸化染料の有効染着領域が消滅し た, (2) 酸化重合反応の触媒として作用寸る反応因子 (CMC 構成成分)が抽出によって除去されたことが考えられる.

そこで,（1）の要因を確かめるためにすべての染色系で
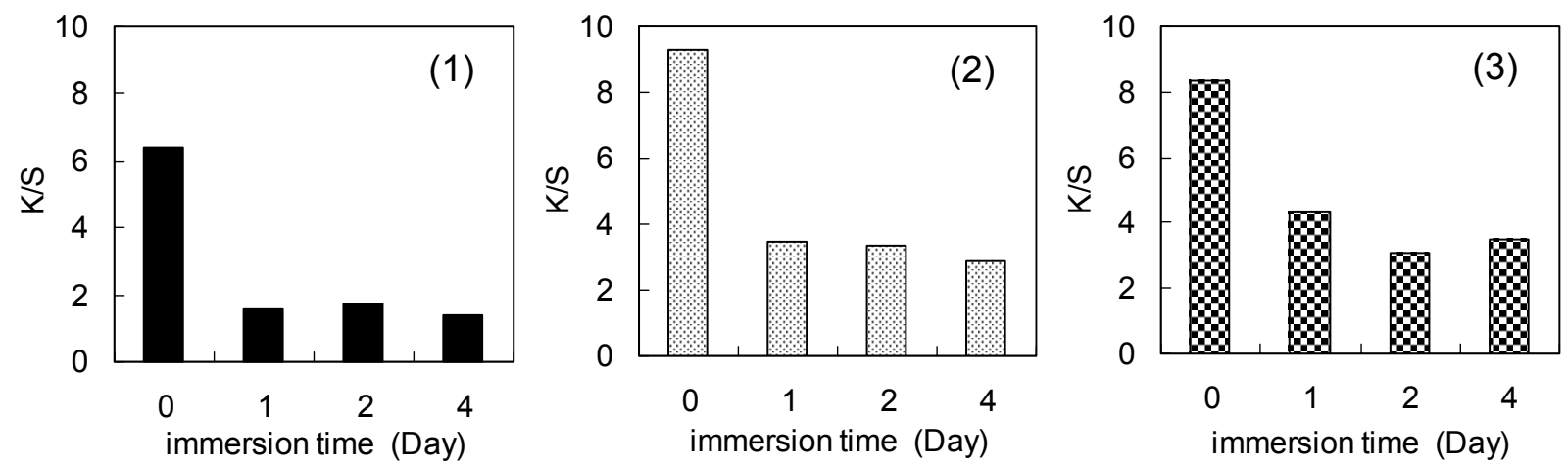

Fig. 7 Dye uptake of formic acid-treated wool fabrics dyed at $30^{\circ} \mathrm{C}$ for $30 \mathrm{~min}$ using the dyeing condition $\mathrm{C}$. (1) $\mathrm{pAP} / \mathrm{pAOC}$ system, (2) pPDA/pAOC system, (3) pAT/pAOC system
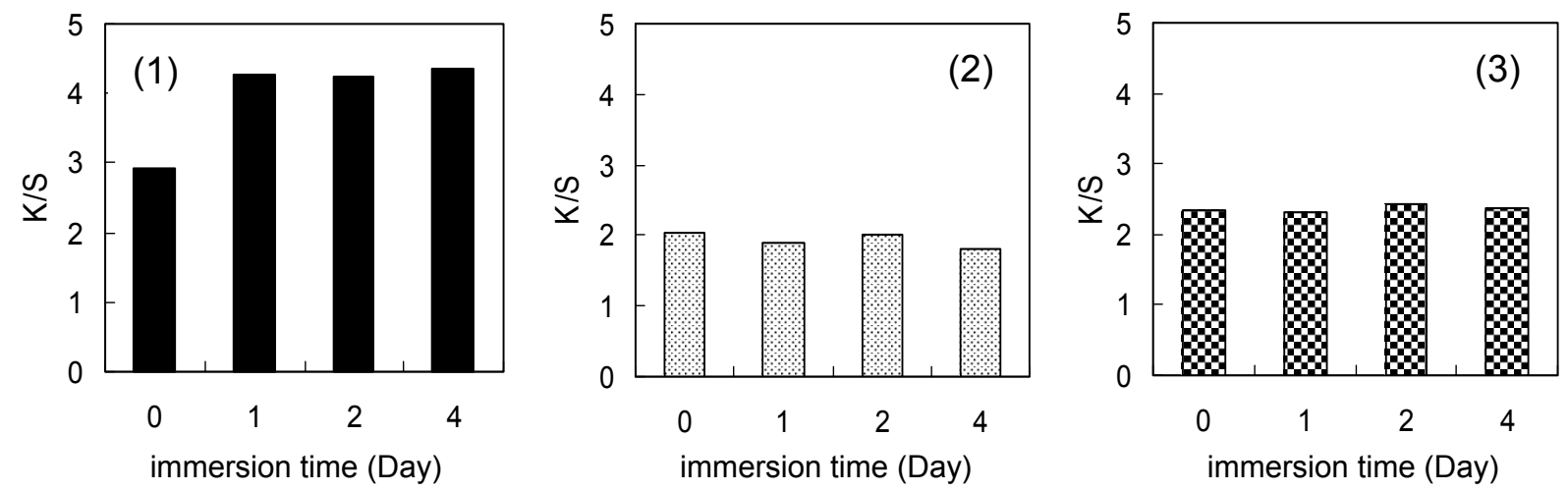

Fig. 8 Dye uptake of formic acid-treated wool fabrics dyed at $30^{\circ} \mathrm{C}$ for $30 \mathrm{~min}$ using the dyeing condition $\mathrm{A}$. (1) $\mathrm{pAP} / \mathrm{pAOC}$ system, (2) pPDA/pAOC system, (3) pAT/pAOC system 
$\mathrm{A}$ 法による未処理羊毛布とギ酸処理布の $30^{\circ} \mathrm{C}, 30$ 分染色 を試み, その結果を図 8 に示した。

この図から, pAP/pAOC 系においては, 未処理羊毛布 に比べギ酸処理羊毛布の K/S 值が増大することが, pPDA/ pAOC 系および pAT/pAOC 系では, 未処理羊毛布に比べ て若干 K/S 值が低下気味であるがほとんど変わらないこ とがわかる。これらの結果から，染着低下の原因が CMC の抽出によって染着領域(座席)が消滅したことによるも のではないことがわかる.

しかしながら, ギ酸処理が CMC 領域だけでなく, コル テックス細胞内にも影響をおよぼしている可能性は拭え ない. そこで，コルテックス細胞に対する酸化染料の染 色性について調べた。

\section{5 コルテックス細胞の染色性}

実験に使用したコルテックス細胞は, 図 9 の光学顕微 鏡写真で見られる紡錘状の形をしたものである。この写 真には, 未分割の繊維片やクチクル細胞なども見ること でき, 粉末は各構成組織成分の混合体である.

図 10 はこの粉末と羊毛布とを $\mathrm{pAP} / \mathrm{pAOC}$ 系で A 法お よび C 法により $30^{\circ} \mathrm{C} ， 30$ 分間染色した結果を表したもの である.この図には比較のため酸性染料である Orange II (pH4.2)で染色した粉末試料も載せたが，粉末は濃い赤橙 色に着色しており, コルテックス細胞の染着性は粉末化 による影響はないものと考えられる。

そこで, 酸化染料での染色であるが，いずれの染色法 によっても既に示したように羊毛布は橙色に染色されて いるのに対して, 粉末試料は, A 法では粉末集合体とし てわずかな着色が見られるが，C法による染色では全く 着色されていないことが確認できる. 寸なわち, コルテッ クス細胞そのものは酸化染料では染色されないと考える ことができる。

結果は省くが, $\mathrm{pPDA} / \mathrm{pAOC}$ 系および $\mathrm{pAT} / \mathrm{pAOC}$ 系に ついても pAP/pAOC 系と同様に粉末は染色されないとす る結果が得られた。すなわち, 本実験で用いた A 法およ

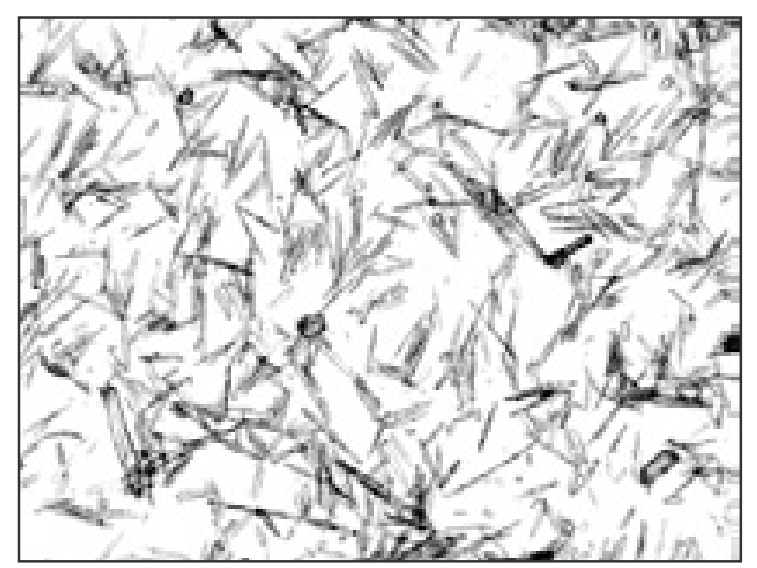

Fig. 9 Photograph of cell fragments of wool mechanically pulverized by a Rotary Mill P-12 (FRITSCH, Germany)

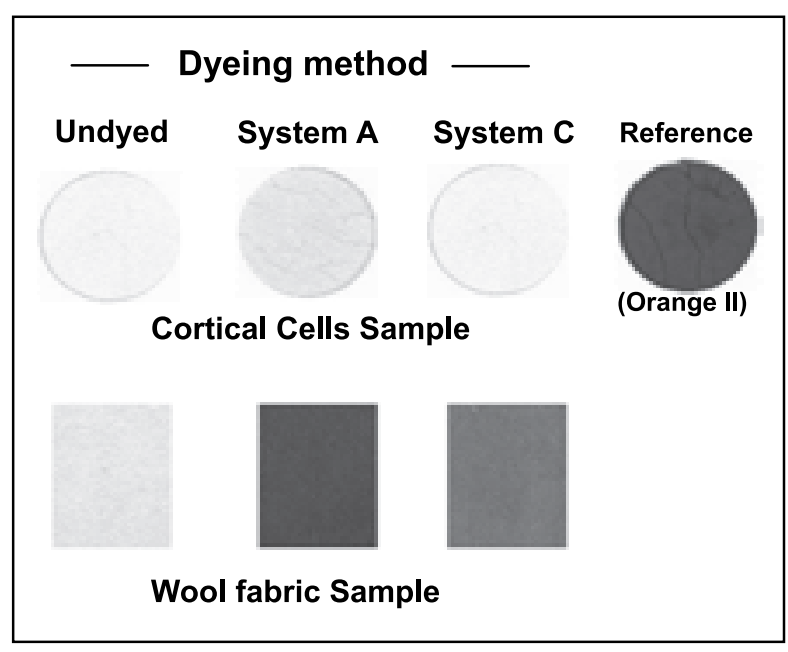

Fig. 10 Samples of wool powder and fabric dyed at $30^{\circ} \mathrm{C}$ for 30min using the dying conditions $\mathrm{A}$ and $\mathrm{C}$

びC 法の染色条件下では，いずれの染色系においてもコ ルテックス細胞には染着しないことから, 酸化染料は主 に CMC 領域に染着していると結論することができる.

したがって, CMC の改質にともなう染着量低下の原因 は, 酸化重合反応の触媒として作用する反忘因子 (CMC 構成成分) が抽出とともに除去されたことが関与している ものと考えられるが，詳細については現在検討中であり 改めて報告することとしたい.

\section{4. 結 論}

本研究では, ケラチン繊維に対する酸化染料の染着機 構や染着領域に関する知見を得ることを目的として，ケ ラチン繊維以外の繊維に対する染色性および羊毛繊維に 対する酸化染料を用いた染色における羊毛繊維の CMC の 構造変化の影響について検討した。

アスコルビン酸と EDTA を添加した染色系 (C 法)で染 色した結果, 羊毛繊維以外の繊維は染色されないことを 見出し, 羊毛繊維に対する酸化染料の染色は羊毛繊維の 固有の組織構成が関与していることが示唆された. そこ で，染料等の浸透経路として役割を果たす CMC の改質の 影響を検討したところ, ギ酸処理により CMC を改質した 繊維の染着量は低下することがわかった。 また, 䋊維よ り分画したコルテックス細胞は酸化染料により染色され ないことも見出された.

以上の結果から, 羊毛繊維への酸化染料の染着にとっ て CMC は酸化染料の染着領域として働くだけでなく, 繊 維上での酸化染料の重合反応に深く関与する触媒因子を 含む組織として重要な役割を果たしていることが明らか となった。

\section{文 献}

1. Y. Arai, "The newest hair coloring Technology" 
Fragrance Journal LTD, Tokyo, (2004).

2. C. Robbins, "Chemical and physical behavior of human hair", 4th Ed. Springer Verlag, New York Berlin, Heidelberg, pp.311-331(2002).

3. J. L. Stoves, J. Soc. Dyers Colurists, 92, 213 (1976).

4. H. Nerenz, P. huppmann, and K. Schrader, Cosmetics \& Toiletries, 116, 55 (2001).

5. J. D. Leeder, J. A. Rippon, F. E. Rothery and I. W. Stapleton, Proc. 7th Int. Wool Text. Res. Conf., Tokyo,
Vol.5. 99 (1985).

6. R. Brady, Rev. Prog. Coloration, 22, 58 (1992).

7. J. H. Bradbury and J. D. Leeder, Appl. Polymer Symp., No.18, 227 (1971).

8. J. D. Leeder D. B. Bishop and L. N. Jones, Text. Res. J., 53, 402 (1983).

9. WRONZ Communication, "The Cell Membrane Complex of Wool - A Critical Assessment of the Literature", No. C123, September (1992). 